\title{
FROM THE HISTORY OF ACTIVITIES OF TRADE CENTERS SERVING FOR PEOPLE IN THE VILLAGES OF FERGHANA VALLEY IN THE 6OS AND 8OS OF XX CENTURY
}

\author{
Tajimirzayev Elyorbek Akramovich \\ Senior teacher at Uzbek History department of Andizhan State University, \\ Republic of Uzbekistan
}

Article DOI: https://doi.org/10.36713/epra3983

\begin{abstract}
The article deals with the provision of trade services to villagers in the Ferghana Valley from 1960 to 1980. In particular, the provision of trade services to the rural population with shops, markets, public catering establishments, shops and consumer services was analyzed on the basis of archival materials and scientific literature.
\end{abstract}

KEY WORDS: Trade Services, District, Rural, Village, Collective Farm, State Farm, School, Kitchen, Shop, Buffet, Food, Public Dining Center.

\section{INTRODUCTION}

From ancient times trade and transit routes have played an important role in the development of nations. In the regions of our country, the first stage of trade services, trade relations, dates back to the Bronze Age. Trade services play a huge role in meeting the daily needs of the population. During the years of independence Uzbekistan has been focusing on the provision of trade services to the population at the level of state policy.In particular, the third point of the Strategy of Action for the five priority areas of development of the Republic of Uzbekistan in 20172021 is the priority of economic development and liberalization, its subsection 3.1 includes issues such as, continuation of policies to reduce the tax burden and simplify the taxation system, continuation of policies to reduce the tax burden and simplify the taxation system, improve tax administration, and expand appropriate incentives; Further improvement of monetary policy using the tools used in the best international practice, as well as the gradual introduction of modern market mechanisms of currency regulation, ensuring the stability of the national currency; deepening and ensuring the stability of the banking system, increasing the level of capitalization and deposit base of banks, strengthening their financial stability and reliability, further expansion of lending to promising investment projects and small businesses and private entrepreneurship [1.]. These reforms contribute directly to improving the provision of trade services to meet the daily needs of the population.
Analyzing the general status of trade services to the population during the Soviet era is one of the important tasks. Therefore, in this article, we have tried to explain the status of trade services to villagers in the Ferghana Valley in the 1960s and 1980s based on archival documents.

Between 1960s and 1980s, markets, shops and public catering facilities served the rural population. In 1960, there were 237 kitchens, 330 buffets and teahouses in 140 state farms in Uzbekistan. The working capital of public catering establishments in state farms in 1959 increased by more than 2 times in 1957. The number of workers and laborers in the kitchens continued to increase. Hot meals were organized at field-houses during busiest periods of field work. Coverage cooperatives have started the work of bakeries, shops and public service establishments in state farms besides public catering facilities [2.P.271].But the kitchen network in the state farms was not enough. Public catering establishments were organized mainly in rural centers. Kitchens were poorly equipped with refrigerators, dishes, process equipment and utensils. Also, most of the dishes made were not tasty, but the prices were high. In addition, there had been occasions when the Directorate of State farms deviated from the daily needs of the population. In particular, they did not provide vegetables to the public catering establishments, nor did they provide kitchen utilities. In addition, rent and electricity bills were very high in establishing kitchens [2. P.272]. 
In 1960s, 382 schools did not have buffets in Andijan. Medical facilities, children's institutions and boarding schools were also undernourished. In rural areas, there was no systematic commission sale of meat, vegetables and other agricultural products. Moreover, pricing was often even more expensive than in the market.

During the period under review, no attention was paid to the provision of public services to the population of the "Southern Olamushuk" and "Polvontosh" oil mining villages. This was also reflected in the protests written to the government about the improvement of trade and public services to the population of the villages [3. P.109].

In Andijan region in 1964 it was planned to open 4 children's clothing stores, yet they were not opened. It was planned to open 29 self-service shops, and only 8 were opened. Semi-finished goods production shops, canteens, cafés and grocery shops were not opened. Book sales in Andijan region were in poor condition. In particular, during the first 8 months of 1961, the regional cooperative organizations did not pick up literature worth 205,000 rubles from the regional bookstore. District printing societies had sent back books sent by the regional book trade organization (Bozsuv, Kholdivonbek and other districts) for lack of textbooks for secondary school students. In the collective and state farms of the region, the provision of trade services to the population during the cotton harvest was not satisfactory [4. P.121].

There had been some positive developments in some areas of the valley during this period. For example, in the 1968-1970s in Akhunbabaev district of Fergana region, 40 stores and kitchens, as well as a number of bakeries were built, which increased the number of trade and catering organizations. The increase in trade working capital through the regional coverage system in 1969 amounted to 3480.7 thousand rubles [5.P.48]. In total, in 1968-1970s, the number of commercial and catering establishments in the Ahunbabaev district increased by 28 and totaled 356 . For example, in the village of Achshak, which had a population of 5518 people, there were 10 shops, and there were 4 retailers and 8 catering places per 1000 population. In the rural district of Gulistan, with a population of $6,183,9$ stores provided commercial services to the population [5. P.55], with 3 retailers and 11 catering places per 1,000 people. In total, the Akununbabaev District Coverage Society had 5 retailers per 1,000 people and 16 places in the catering sector, which was higher than the regional average. In 1970, the working capital of the RCS was 3488.7 thousand rubles [5. P.56].

However, some villages in Akhunboboev district of Ferghana region did not have commercial service facilities at all or did not provide adequate public services. For example, 7 out of 18 rural areas of Saddinisky rural district had a population of 4.5 thousand, but there were no stationary trading facilities.
It was $1.5-3 \mathrm{~km}$ to visit the shops in the villages nearest to these villages which required the inhabitants to walk that far distance to meet their needs [5. P.51]. This had a negative impact on the living standards of the population. There was also a shortage of first-time consumer goods in stores in the valley areas [6. P.217].

For example, in the 1969 and 1970, mugs and soft blankets were not brought to the shops of the village councils of Ahunboboev district. Some shops did not have glasses, knives, enameled and aluminum kettles, handbags, and axes [5. P.58]. Therefore, per capita product sales in 1970 increased by only 30 per cent compared to 1969 [5.B.57]. From 1971 to 1975, the volume of retail trade in the Ferghana region increased by $49.9 \%$, in rural areas it was $54.4 \%$. In other words, rural areas had a higher working capital than the regional ones [6. P.217].

In 1971, as a result of measures taken to boost cooperative sales by the Provinces of the Namangan Regional Coverage Society and the subordinate organizations of the local cooperative, the annual working capital amounted to 213468 thousand soums instead of 211949 soums, and the sale of industrial and food products exceeded by 1519 soums. The annual growth rate was $7.3 \%(14,500,000)$ [7.P.20]. However, the implementation of the annual plan was not homogeneous across the sub-coverage and cooperatives. In particular, the sales amounted to Chust district demand union - 350,900, Namangan demand union - 717,9 thousand, Uchkurgan district demand union - 267,7 thousand, Shakhand coverage society 218,5 thousand sums whereas had sales under the planned figure for Uychi district coverage society - 607 thousand, Chust coverage society - 309 thousand, Yangikurgan coverage society - 425 thousand and Lenin labor cooperative - 60 thousand soums. As a result, the regional coverage society sold industrial and food products to the villagers for less than 1351 thousand soums. This was evidenced by the fact that according to the results of 1972, 838 out of 996 enterprises of the coverage society of Namangan region had fulfilled their annual plan, while 157 stores had not fulfilled the annual plan. In particular, 46 (64.8 per cent) businesses in the Uychi District Coverage Company and 15 in Zadarya District (22 per cent) [7.P.21] did not meet the annual plan.

Despite the fact that Namangan regional party committee and the regional executive committee had repeatedly stated that the sale of some goods was unsatisfactory, and the failure of the regional coverage cooperative to address these shortcomings there could be seen as a disruption in the sale of goods listed in the minimum. In particular, in 1971, the sale of 15 types of goods declined in comparison with 1970 . This can be seen from the low sales of cotton oil for 60,000 sums, canned meat for 166,000 sums and silk fabrics for 497,000 sums.

The lack of daily consumer goods in shops had led to the decline in labor productivity of collective and 
state farms. People had to travel dozens of kilometers to get the goods they needed. Many shops in the villages of the region were not provided with the essential goods. For example, during the check-up of the assortment of goods listed in the minimum at a convenience shop under the cabinet of Worker's Cooperation named after Lenin there was no dry tea, cotton oil, pasta, butter and cigarette, at the same time there were no children's suit and shirt made of natural fiber, toothbrush and pins at the "Ilgor" department store which was under the cabinet of Umurzokov coverage society. At the shop numbered 6 within the same coverage society there was no diverse semolina, pasta, food concentrates, dry tea, sugar, measurably sold biscuits, various jams, tomato pastas, vegetable tins, butter and matches [7.P.22-24].

In 1972, Namangan region carried out a number of works in accordance with the decision of the Council of Ministers of the UzSSR from February 22, 1972, of the Central Committee of the Communist Party of the USSR and the Council of Ministers of the USSR dated January 7, 1972 "On some measures to improve trade and its equipment". In particular, this year, 37 refrigerators were installed in trade, catering and manufacturing, with 633 units in the region. However, due to insufficient attention to the technical condition of the existing refrigerators by the heads of cooperative organizations, the technical department of the coverage and the repair department, about $50 \%$ of the refrigerators did not work this year [7.P.200].

The construction of a number of facilities in Namangan Region had not been completed for several years due to the irresponsibility of the construction companies and contractors. In particular, there was a general kitchen for 75 seats in Kossansay village, a shop for 6 workers in the collective farm "Leningrad", 2400 sq. M. 5,000 sq. m. of drying warehouse and 10 construction trust which were under construction, the construction of the Naryn and Turakurgan wholesale warehouses began in 1966, construction and yet it was not completed in 1972. In addition, 284,000 sums were allocated to the construction of the Naryn base that year, which amounted to 208.4 thousand sums (73.4\%), and Turakurgan base worth 62.4 thousand sums (36.1\%) from 173 thousand. [7.P.199 ].

In the Namangan region during the period 1971-1973 and within 9 months of 197417 grocery stores owning 1718 sq.m. of land [8.P.65], 5 pavilion shops, 1 vegetable market with 200 sq.m. of total area, potato storage with 7,000 tons of volume and 46 catering establishments were opened. Certain work on construction and improvement of collective farms was carried out in Namangan region. In particular, a fruit and vegetable trade pavilion for 140 seats was opened in Chust. In 1972 another pavilion was opened in Uchkurgan. Agricultural products at the collective farms in cities and regions had been growing year by year. 125,440 tons of vegetables and fruits were sold instead of 103690 tons planned for 1971-1973 and 9 months of 1974 [8.P.66].

During the first 9 months of 1973 in the Chortoq rural coverage society of the Yangikurgan district, 1 department store, 2 shops of industrial goods, 1 clothing store, 1 oil products store, 4 shops of cultural goods, 1 bookshop, 6 shops for household goods, 1 shop selling products designed for children, 2 groceries, 1 gastronomic shops, 1 bakery, 1 dairy product, 38 daily needs shops and in total there were a total of 62 shops running [9.P.275].

In 1973, there were 440 rural shops which were serving for the needs of customers in Namangan region [10.P.2]. Of these, during the spring field work in 1973,150 rural shops without sales assistants, 94 truck-delivered shops, 120 mobile shops and 84 busshops operated in rural areas [10.P.3].

Also, during the study period, kitchens and canteens served for students and teachers in schools. For example, in the province of Namangan in the 19741975 school year, 445 rural schools had 235 buffets (1,450 seats) and 134 canteens (4,980 seats) [9.P.3]. As 49 schools were transferred to state farms and the administration of supply service for laborers, the state administrations provided food for the students. In 39 schools, there were few students and they were attached to nearby stores. In each area, the school's cafeterias had been attached to schools to provide school buffets and canteens. They also offered biscuits, coriander, croissants, and cookies. School canteens with dumplings and dim sum had been set up in Kosonsay, Turakurgan, Namangan, Naryn and Uychi districts.

Although kitchens and canteens of rural schools in the Namangan region were provided with refrigerators, many of them did not work. In addition, most of the school's cafeterias were not adapted to it and did not meet sanitary regulations. Most of the buffets and canteens had no floor or ceiling coverage. For example, schools 14, 22 and 32 of Turakurgan district, schools 17, 21 and 22 of Uchkurgan district, schools 20 and 35 of Namangan district, cafeterias and canteens of schools No 15, 16 and 17 of Naryn district had no floors and ceiling coverage. [10.P.4].

In 1975, the department of catering in Chust district of Namangan region signed an agreement with 22 rural schools to provide buffets and canteens with food. From September 1 to November 1, schools in Chust District were supplied with $25 \mathrm{kgs}$ of peanuts, 61 cans of juice, and 60,000 cakes made in school canteens in October. Experts had criticized school buffets for failing to make coffee and cocoa because of the lack of eggs and milk [9.P.7].

In 1975, there were 28 buffets and 15 canteens for 100 seats in 42 schools in the Pop District, 6 schools were attached to the Nayman and Pop state farms, and four schools to "Chodak" and "Kokand" departments of food supply for laborers. There were no refrigerators and other process equipment in the school buffets in the Pop District. 
There were buffets and canteens in 39 out of 46 schools in Chust district, 23 out of 38 schools in Kosonsoy district and 34 out of 42 schools in Uychi district. However, most of these buffets and kitchens were not equipped with refrigerators and other appliances [9.P.24].

In the 1975-1976 school year, there were 27 rural schools in the Yangikurgan district of Namangan region, where 15,682 students were educated. There were 14 canteens ( 620 seats) and 25 buffets ( 740 seats) in 27 schools. That was, $8.3 \%$ of rural school students who were provided with buffets and canteens [9.P.46].

In 1976-1980 the per capita working capital of the urban population increased by $24.3 \%$, while in the rural population it was $17.9 \%$. In 1981-1985, trade capital was steadily declining. Commodity capital in cities was $15 \%$, in rural areas - 9.6\%. In 1985, rural per capita capital was 2.5 times lower than in urban areas [11.P.26].

In 1981-1985 new plants and workshops were launched in rural areas, including 3 canned goods, 10 sausages, 5 smoked fish, 10 confectionery products, 7 ice creams, 8 soft drinks factories and workshops [11. P.15].

In 1985, with the decline of alcohol sales, great attention was paid to the production of juice, kvass, and ice cream. Various service points had been set up for the sale of Lola type probes. Per capita index of development of rural catering establishments was more detailed. In 1975-1985, the per capita food capital in rural areas increased by $55 \%$ and in urban areas by $17 \%$ [11.P.15].

In 1985, the area of shops of the Soviet Socialist Republic of Uzbekistan was 54.1 thousand square meters which was an increase. Of these, 20.9 thous.was at the expense of reconstruction. In the beginning of 1986 the area of trade in rural areas was $1,400,000$ sq. $\mathrm{m}$. There were 16,154 stores. In the early 1980 s, much attention was paid to the creation of specialty shops in rural areas. In 1985 there were 66 malls, 410 department stores and 4711 specialized shops selling industrial products in the villages. There were also 8009 daily consumer shops. In 1985,14140 stores or $87 \%$ of all stores were self-service [11.P.13]. However, despite the expansion of trade and consumer services in the countryside, the population had often been forced to attend district centers and cities due to a shortage of essential goods. In a sociological survey conducted by sociologists in the villages of Andijan in 1987, 63 percent of respondents answered the question of, "Why do you want to go to the city?" and their responses were "to buy goods and to be in the consumer services business ". Less than half of the respondents were satisfied with the work of commercial and consumer services businesses, $32.1 \%$ were not satisfied with the variety of goods in shops. $43.3 \%$ said that they should set up television or radio equipment in a collective farm or state farm, 34.2\% needed to repair refrigerators, and $30.0 \%$ to build and repair shoes.
Consequently, the rural population's demand for these types of services was not satisfactory [12.P.98-99]. In addition, the answers to the question "How do you rate rural trade?" the distribution among the population of Andijan region villages as follows: Good - $45.3 \%$, bad $15.3 \%$, Business mode $-4.1 \%$ Not enough - -, Offshore stores $-3.2 \%$, no necessary goods - 32.1\% [12.P.99].

In the early $1980 \mathrm{~s}$, the production of national bread in the villages of Namangan region was $68.4 \%$, an increase of $6.5 \%$ compared to 1979 . Per capita consumption of bread and bakery products was 167 grams per day [10.P.14]. In the early 1980s, the loaf consisted of 25 kopecks, $13 \mathrm{~kg}$ of baton of $0.5 \mathrm{~kg}$ of first grade flour, $11 \mathrm{~kg}$ of $0.4 \mathrm{~kg}$ of freshly baked bread, 16 kopecks of the second grade [10. P.15]. The first type of $0.4 \mathrm{~kg}$ of patties was 18 kopecks [10.P.18] The first grade of $0.2 \mathrm{~kg}$ was 6 kopecks and 9 kopecks with a weight of $0.3 \mathrm{~kg}$ [10.P.19].

The bakery industry was significant parts of the total turnover of «Uzbekbirlashuv» and operated in 226 bakeries in 1985 and 2,791 tonnes of bread were made per day. The range of bakery products had also improved during these years. In 1985, 70 types of bakery products were produced, with the total national bread making up 48.1\% [11.P.14].

During the period under review, trade services to the rural population were low. In many settlements there were no commercial enterprises or public catering establishments until 1985. More than 3,000 rural settlements $(1,262,000$ people) did not have trade enterprises. 8,375 rural settlements (5238 thousand people) did not have catering facilities. They was forced to attend a grocery store $10 \mathrm{~km}$ away or more in 152 villages with a population of 77,000 [11.P.14].

The development of public catering facilities in rural areas was also considered. In the system of coverage cooperatives in 1986 there were 10322 catering establishments with 443.8 thousand seats. In 1981-1985 the growth in this area was 81.1 thousand [10.P.14].

One of the most important indicators of rural life was an increase in the average per capita capital, which was 319 rubles in 1975, 405 rubles in 1980 and 447 rubles in 1985 , and increased by 40.1 percent in 10 years. In cities, this figure increased by 35.7 percent.

In conclusion, during this period, markets, shops, teahouses, buffets and canteens provided services to the rural population. In addition, hot meals were served in the field. During the agrarian activities, mobile shops were established and people were provided with trade services there. Buffets and canteens set up in kindergartens and schools served for children, but there were problems with the provision of adequate food and it was, in most cases, in poor quality. By the end of the period, trade services for the population had declined significantly. 


\section{REFERENCES}

1. Strategy of Action for the Five Priorities of Development of the Republic of Uzbekistan for 2017-2021, listed in Annex 1 to the Decree of the President of the Republic of Uzbekistan dated February 7, 2017 № 4947 // http://strategy.regulation.gov.uz

2. National State Archives of the Republic of Uzbekistan (CSA of the Republic of Uzbekistan), $R$ 90 stock, list 10, work 3043.

3. UzR CSA, stock $R-837$, list 39 , case 552

4. UzR CSA, R-217 fund, list 10, 7 work

5. UzR CSA, R-2454 fund, list 6, case 2019

6. State Archives of Fergana region, fund $R-1124$, list 13, work 108

7. Namangan State Archives $R-80$ fund, list 3, 785 works

8. UzR CSA, fund R-837, list 41 , case 3454

9. Namangan regional state archive $R-80$ fund, list 3 , work 818

10. Namangan regional state archive $R-80$ fund, list 3 , work 815

11. UzR CSA, fund R-837, list 41 , case 7061

12. Egamov E., Mehmonov S. Rural Livelihoods: Problems and Solutions. $-T$.: "Labor," 1991 (Эгамов Э., Мехмонов С. Қишлоқ ахолисининг турмуш шарочти: муаммо ва ечимлар. -T.: “Мехунат”, 1991) 